Review

\title{
ARTIKEL REVIEW : FORMULASI DAN EVALUASI SEDIAAN EFERVESEN HERBAL SEBAGAI ANTIOKSIDAN
}

\section{REVIEW ARTICLE : FORMULATION AND EVALUATION HERBAL EFFERVESCENT DOSAGE FORM AS ANTIOXIDANT}

\author{
Yolanda Putri Aloenida ${ }^{1}$, Garnadi Jafar ${ }^{2}$, Fenti Fatmawati ${ }^{3}$ \\ Fakultas Farmasi, Universitas Bhakti Kencana, Bandung, Indonesia, 40614 \\ *E-mail: fenti.fatmawati@bku.ac.id
}

Diterima: $16 / 03 / 2021$

Direvisi: 22/03/2021

Disetujui: 29/04/2021

\begin{abstract}
Abstrak
Besarnya pengaruh radikal bebas terhadap kesehatan manusia membuat masyarakat saat ini banyak mengkonsumsi buah dan sayur serta bahan alam lain tinggi antioksidan. Untuk mendapat dan mengefisiensikan manfaat antioksidan dari herbal dibutuhkan adanya suatu teknologi yang tepat salah satunya dibuat dalam sediaan efervesen. Sediaan efervesen memiliki beberapa keunggulan yaitu memiliki rasa yang enak, mudah dikonsumsi dan diabsorbsi cepat oleh tubuh. Review ini memberikan informasi mengenai formulasi dan evaluasi sediaan efervesen dari berbagai herbal sebagai antioksidan. Kombinasi asam sitrat dan asam tartrat serta natrium bikarbonat dengan metode granulasi basah menjadi formulasi yang paling banyak digunakan. Evaluasi waktu larut, $\mathrm{pH}$, dan kadar air sediaan menjadi indikator kualitas sediaan efervesen. Metode DPPH menjadi pilihan yang paling banyak digunakan untuk menguji aktivitas antioksidan dalam sediaan. Sediaan efervesen dapat menjadi bentuk penghantar antioksidan dari berbagai herbal. Ekstrak daun teh dan daun sirsak, ekstrak daun amla, ekstrak kulit buah manggis serta ekstrak buah jeruk cakar harimau dalam bentuk sediaan tablet efervesen memberikan aktivitas antioksidan yang paling kuat.
\end{abstract}

Kata kunci: Antioksidan; Efervesen; Evaluasi; Formulasi; Herbal

\begin{abstract}
The effect of free radicals on human health has influenced people to consume more natural products with high antioxidants compound. In order to prepare antioxidant formulation containing a related compounds, one of which is made in effervescent. Effervescent has several advantages including ease of consumtion, having good taste and rapid absorption. This review provides information regarding the formulation and evaluation of effervescent of various herbs as antioxidants. The combination of citric acid and tartaric acid and sodium bicarbonate by wet granulation method is the most widely used formulation. Evaluation of solubility time, $\mathrm{pH}$, and water content of effervescent is an indicator of the quality of effervescent. As a quality control for herbal antioxidant activity in effervescent, the DPPH method is widely used. Effervescent can be a form of antioxidant delivery from various herbs. Soursop leaves and tea leaves extract, amla leaves extract, mangosteen peel extract and foshou fruit extract in effervescent tablet form has very strong antioxidant activity.
\end{abstract}

Keywords: Antioxidant; Effervescent; Evaluation; Formulation; Herbal 


\section{PENDAHULUAN}

Kecenderungan memanfaatkan bahan alam sebagai obat saat ini sangat digemari masyarakat Indonesia [1] . Kandungan metabolit sekunder dalam tanaman herbal memiliki aktivitas farmakologis yang dapat dimanfaatkan untuk kesehatan salah satunya sebagai antioksidan [2] . Antioksidan dapat membantu menurunkan kadar ROS (reactive oxygen species) yang merupakan senyawa radikal bebas [3] . Ketidakseimbangan antara manifestasi spesies oksigen reaktif dan kemampuan biologis tubuh untuk mendegradasi ROS dengan cepat dapat menyebabkan stres oksidatif sehingga merusak sel-sel tubuh $[4,5]$.

Antioksidan terdapat pada berbagai jenis tanaman, diantaranya kandungan antosianin pada buah salam (Syzygium polyanthum) dan betasianin pada kulit buah naga merah (Hylocereus polyrhizus) [6]. Senyawa fenolik pada kulit buah rambutan (Nephelium lappaceum L.) bertanggung jawab sebagai antioksidan [7]. Daun beluntas juga berpotensi sebagai sumber antioksidan karena kandungan flavonoid yang cukup tinggi [8]. Mekanisme pertahanan golongan flavonoid terhadap oksidan bekerja melalui prinsip netralisir radikal bebas dengan memberikan satu elektron kepada molekul yang reaktif [9].

Untuk mengoptimalkan aktivitas farmakologis antioksidan dari suatu tanaman, diperlukan adanya suatu teknologi yang tepat untuk mempermudah penghantaran dan mengefisiensikan manfaat yang akan didapat sehingga diharapkan dapat meningkatkan kepatuhan pasien dan berdampak pada tercapainya tujuan terapi $[10,11]$. Salah satu upaya yang dapat dilakukan adalah dibuat dalam bentuk sediaan efervesen [12] . Dewasa ini, sediaan efervesen popular sebagai terapi preventif dan kuratif seperti suplemen dan minuman kesehatan baik dalam bentuk granul maupun tablet [13].

Sediaan efervesen merupakan salah satu bentuk penghantaran obat yang memiliki beberapa keunggulan [14]. Sediaan efervesen diketahui sebagai suatu sediaan yang dapat menghasilkan gas saat bereaksi dengan air sehingga memberikan sensasi segar serta mampu menutupi rasa pahit zat aktif saat dikonsumsi [15,16]. Jika dibandingkan dengan tablet konvensional, tablet efervesen sangat tepat diberikan kepada pasien yang sulit menelan tablet karena obat pada sediaan ini dikonsumsi dalam bentuk sudah terlarut [17]. Hal ini dapat memperbaiki profil farmakokinetik dengan mempercepat proses disintegrasi sehingga obat dapat langsung diabsorpsi oleh tubuh [18,19]. Karena keunggulan tersebut, maka sediaan efervesen dapat menjadi pilihan bagi pasien untuk tujuan pengobatan atau memenuhi asupan suplemen dalam menjaga kesehatan [13]. Oleh karena itu, review artikel ini diharapkan dapat memberikan informasi terkait dengan formulasi dan evaluasi dari berbagai herbal yang dibuat dalam bentuk sediaan serbuk, granul atau tablet efervesen sebagai antioksidan.

\section{Formulasi Sediaan Efervesen}

Proses pembuatan sediaan efervesen dapat dilakukan dengan beberapa metode formulasi. Pada metode formulasi granulasi basah sediaan granul maupun tablet efervesen menggunakan pelarut organik seperti etanol dan isopropil alkohol untuk melarutkan bahan pengikat [20,21].

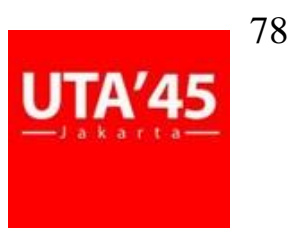


Selain itu, sumber asam dan basa yang digunakan sedapat mungkin dalam bentuk anhidrat untuk mengurangi jumlah molekul air dalam sediaan serta diproses secara terpisah. Hal-hal tersebut dilakukan untuk mencegah terjadinya reaksi efervesen selama proses pembuatan serta menjaga stabilitas sediaan efervesen [22]. Pada Tabel 1 ditunjukkan penggunaan kombinasi sumber asam menjadi formulasi yang paling banyak digunakan karena dapat memberikan keuntungan [20]. Penggunaan sumber asam tunggal seperti asam sitrat akan menghasilkan sediaan efervesen yang rapuh, mudah menggumpal dan produk akhir cenderung memiliki rasa asin. Sedangkan penggunaan tunggal asam tartrat akan menghasilkan campuran yang lengket dan sukar digranulasi [23]. Jenis sumber asam lainnya yang dapat digunakan dalam sediaan efervesen adalah asam malat dan asam fumarat [22]. Pada Tabel 1 juga dijelaskan natrium bikarbonat lebih banyak digunakan sebagai sumber basa. Hal tersebut dikarenakan penggunaan natrium bikarbonat akan lebih cepat bereaksi dan menghasilkan gas karbondioksida yang lebih banyak [23]. Sumber basa lain yang dapat digunakan dalam sediaan efervesen adalah natrium karbonat dan kalium bikarbonat.

Tabel 1. Sumber Asam dan Basa Pada Beberapa Formulasi Sediaan Efervesen

\begin{tabular}{|l|l|l|l|l|l|l|}
\hline \multirow{2}{*}{ No } & \multirow{2}{*}{$\begin{array}{c}\text { Asal } \\
\text { Negara }\end{array}$} & $\begin{array}{c}\text { Jenis } \\
\text { Sediaan } \\
\text { Efervesen }\end{array}$ & \multicolumn{1}{|c|}{$\begin{array}{c}\text { Metode } \\
\text { Pembuatan }\end{array}$} & \multicolumn{1}{|c|}{ Sumber Asam } & \multicolumn{1}{|c|}{ Sumber Basa } & Pustaka \\
\hline 1. & Indonesia & Serbuk & Pencampuran & Asam sitrat & $\begin{array}{l}\text { Natrium karbonat } \\
\text { Natrium bikarbonat }\end{array}$ & {$[24]$} \\
\hline 2. & Indonesia & Serbuk & Pencampuran & $\begin{array}{l}\text { Asam sitrat } \\
\text { Asam tartrat }\end{array}$ & Natrium bikarbonat & {$[25]$} \\
\hline 3. & Indonesia & Serbuk & Pencampuran & Asam malat & Natrium bikarbonat & {$[23]$} \\
\hline 4. & Indonesia & Serbuk & Pencampuran & $\begin{array}{l}\text { Asam sitrat } \\
\text { Asam tartrat }\end{array}$ & Natrium bikarbonat & {$[8]$} \\
\hline 5. & Indonesia & Serbuk & Pencampuran & Asam sitrat & Natrium bikarbonat & {$[26]$} \\
\hline 6. & Indonesia & Granul & Granulasi Basah & $\begin{array}{l}\text { Asam sitrat } \\
\text { Asam tartrat }\end{array}$ & Natrium bikarbonat & {$[20]$} \\
\hline 7. & Indonesia & Granul & Granulasi Basah & $\begin{array}{l}\text { Asam sitrat } \\
\text { Asam tartrat }\end{array}$ & Natrium bikarbonat & {$[27]$} \\
\hline 8. & Spanyol & Granul & Granulasi Basah & Asam tartrat & Natrium bikarbonat & {$[21]$} \\
\hline 9. & India & Granul & Granulasi Basah & $\begin{array}{l}\text { Asam sitrat } \\
\text { Asam tartrat }\end{array}$ & Natrium bikarbonat & {$[28]$} \\
\hline 10. & Indonesia & Tablet & Granulasi Basah & Asam sitrat & Natrium bikarbonat & {$[29]$} \\
\hline 11. & Indonesia & Tablet & Granulasi Basah & $\begin{array}{l}\text { Asam sitrat } \\
\text { Asam tartrat }\end{array}$ & Natrium bikarbonat & {$[7]$} \\
\hline 12. & Indonesia & Tablet & Kempa Langsung & $\begin{array}{l}\text { Asam sitrat } \\
\text { Asam tartrat }\end{array}$ & Natrium bikarbonat & {$[30]$} \\
\hline 13. & Indonesia & Tablet & Granulasi Basah & Asam sitrat & Natrium bikarbonat & {$[31]$} \\
\hline 14. & Indonesia & Tablet & Kempa Langsung & $\begin{array}{l}\text { Asam sitrat } \\
\text { Asam tartrat }\end{array}$ & Natrium bikarbonat & {$[6]$} \\
\hline 15. & Turki & Tablet & Granulasi Basah & - & - & {$[2]$} \\
\hline 16. & China & Tablet & Kempa Langsung & Asam sitrat & Natrium bikarbonat & {$[32]$} \\
\hline 17. & Malaysia & Tablet & Kempa Langsung & - & - & {$[33]$} \\
\hline & & & & & \\
\hline
\end{tabular}


Natrium karbonat atau bikarbonat mengandung molekul $\mathrm{CO}_{3}$ dan saat dilarutkan dalam air akan bereaksi dengan ion hidrogen dari sumber asam seperti asam sitrat, asam tartrat, asam fumarat maupun asam malat sehingga akan membentuk garam natrium, molekul air dan karbon dioksida yang dapat dilihat sebagai gelembung-gelembung dalam air yang mengapung ke atas permukaan. Reaksi efervesen yang terjadi sebagai berikut [13] :

$$
\mathrm{C}_{6} \mathrm{H}_{8} \mathrm{O}_{7} . \mathrm{H}_{2} \mathrm{O}+3 \mathrm{NaHCO}_{3}(\mathrm{aq}) \rightarrow \mathrm{Na}_{3} \mathrm{C}_{6} \mathrm{H}_{5} \mathrm{O}_{7}+4 \mathrm{H}_{2} \mathrm{O}+3 \mathrm{CO}_{2}(\mathrm{~g}) \uparrow
$$

\section{Gambar 1. Reaksi efervesen asam sitrat dengan natrium bikarbonat}

Komponen penting lain dalam formulasi sediaan efervesen adalah zat aktif berupa ekstrak kering dari berbagai herbal yang didapatkan melalui proses ekstraksi yang sesuai dan kemudian diproses kembali untuk mendapatkan ekstrak kering. Ekstrak kering herbal didapatkan dengan menambahkan sejumlah maltodekstrin atau dekstrin [14]. Penelitian Purwati menjelaskan maltodekstrin lebih baik daripada dekstrin sebagai bahan pengisi pada ekstrak herbal [29]. Maltodekstrin memiliki kelarutan dan kemampuan mengikat pigmen, aroma dan rasa ekstrak herbal yang lebih kuat. Penggunaan maltodekstrin juga dapat melindungi komponen nutrisi seperti antioksidan pada sediaan [34]. Sedangkan pada penelitian Madhavi dan Zea ekstrak kering herbal didapatkan dengan cara freeze drying [27,32].

Tabel 2. Formulasi Optimum Sediaan Efervesen

\begin{tabular}{|c|c|c|c|c|}
\hline Zat Aktif & Pengisi Ekstrak & \multicolumn{2}{|c|}{ Formulasi Paling Optimum } & Pustaka \\
\hline Ekstrak bunga belimbing wuluh & Maltodekstrin & $\begin{array}{ll}\text { 1. } & \text { Sorbitol } \\
\text { 2. } & \text { Natrium karbonat } \\
\text { 3. } & \text { Natrium bikarbonat } \\
\text { 4. } & \text { Asam sitrat } \\
\text { 5. } & \text { Asam askorbat } \\
\text { 6. } & \text { Asam stearate }\end{array}$ & $\begin{array}{l}0,2 \mathrm{~g} \\
0,01 \mathrm{~g} \\
1,36 \mathrm{~g} \\
1,05 \mathrm{~g} \\
0,01 \mathrm{~g} \\
0,06 \mathrm{~g}\end{array}$ & {$[24]$} \\
\hline $\begin{array}{l}\text { Ekstrak cincau, daun pandan dan } \\
\text { jahe merah }\end{array}$ & Dekstrin & $\begin{array}{ll}\text { 1. } & \text { Asam sitrat } \\
\text { 2. } & \text { Asam tartrat } \\
\text { 3. } & \text { Natrium Bikarbonat } \\
\text { 4. } & \text { Stevia } \\
\text { 5. } & \text { PVP }\end{array}$ & $\begin{array}{l}12 \% \\
6 \% \\
12 \% \\
5 \% \\
2 \%\end{array}$ & {$[25]$} \\
\hline Ekstrak daun mengkudu & Maltodekstrin & $\begin{array}{l}\text { 1. Natrium bikarbonat } \\
\text { 2. Asam malat } \\
\text { 3. Aspartam }\end{array}$ & {$[-]$} & {$[23]$} \\
\hline $\begin{array}{l}\text { Ekstrak daun beluntas, Ekstrak } \\
\text { jahe merah }\end{array}$ & Dekstrin & $\begin{array}{ll}\text { 1. } & \text { Asam sitrat } \\
\text { 2. } & \text { Asam tartrat } \\
\text { 3. } & \text { Natrium bikarbonat } \\
\text { 4. } & \text { Gula stevia } \\
\end{array}$ & $\begin{array}{l}12 \% \\
10 \% \\
20 \% \\
22 \%\end{array}$ & {$[8]$} \\
\hline Ekstrak miana & Dekstrin & $\begin{array}{l}\text { 1. Asam sitrat } \\
\text { 2. Natrium bikarbonat } \\
\text { 3. Aspartam }\end{array}$ & $\begin{array}{l}5 / 10 / 15 \% \\
10 \% \\
1 \% \\
\end{array}$ & [26] \\
\hline Ekstrak daun gambir & Dekstrin & $\begin{array}{l}\text { 1. PVP } \\
\text { 2. Asam sitrat } \\
\text { 3. Asam tartrat } \\
\text { 4. Natrium bikarbonat } \\
\text { 5. Manitol ( } 75 \text { bagian) }\end{array}$ & $\begin{array}{l}2 \% \\
11 \% \\
14 \% \\
25 \% \\
15,8 \% \\
\end{array}$ & {$[20]$} \\
\hline
\end{tabular}




\begin{tabular}{|c|c|c|c|c|}
\hline & & 6. Acesulfame ( 25 bagian) & $5,2 \%$ & \\
\hline Ekstrak daun teh dan daun sirsak & {$[-]$} & $\begin{array}{ll}\text { 1. } & \text { Asam sitrat } \\
\text { 2. } & \text { Asam tartrat } \\
\text { 3. } & \text { Natrium bikarbonat } \\
\text { 4. } & \text { PVP } \\
\text { 5. } & \text { Natrium benzoate } \\
\text { 6. } & \text { Sakarin } \\
\text { 7. } & \text { Laktosa } \\
\end{array}$ & $\begin{array}{l}8 \% \\
26 \% \\
33 \% \\
1,4 \% \\
1 \% \\
0,5 \% \\
\text { add } 100 \%\end{array}$ & [27] \\
\hline Ekstrak sayuran kering & {$[-]$} & $\begin{array}{ll}\text { 1. } & \text { Asam tartrat } \\
\text { 2. } & \text { Natrium bikarbonat } \\
\text { 3. } & \text { PVP } \\
\text { 4. } & \text { Sukrosa }\end{array}$ & {$[-]$} & [21] \\
\hline Ekstrak daun amla & $\begin{array}{l}{[-] \text { menggunakan }} \\
\text { proses freeze } \\
\text { drying }\end{array}$ & $\begin{array}{ll}\text { 1. } & \text { Asam sitrat } \\
\text { 2. } & \text { Asam tartrat } \\
\text { 3. } & \text { Natrium bikarbonat } \\
\text { 4. } & \text { PVP }\end{array}$ & {$[-]$} & [28] \\
\hline Ekstrak secang dan labu siam & Maltodekstrin & $\begin{array}{ll}\text { 1. } & \text { Asam sitrat } \\
\text { 2. } & \text { Natrium bikarbonat } \\
\text { 3. } & \text { Aspartam } \\
\text { 4. } & \text { PVP } \\
\text { 5. } & \text { Manitol } \\
\text { 6. } & \text { Laktosa }\end{array}$ & {$[-]$} & [29] \\
\hline Ekstrak kulit buah rambutan & Aerosil & $\begin{array}{ll}\text { 1. } & \text { Asam sitrat } \\
\text { 2. } & \text { Asam tartrat } \\
\text { 3. } & \text { Natrium bikarbonat } \\
\text { 4. } & \text { PVP } \\
\text { 5. } & \text { Aspartam } \\
\text { 6. } & \text { Manitol } \\
\text { 7. } & \text { Magnesium Stearat } \\
\end{array}$ & $\begin{array}{l}337,6 \mathrm{mg} \\
361,7 \mathrm{mg} \\
404,9 \mathrm{mg} \\
50 \mathrm{mg} \\
10 \mathrm{mg} \\
202 \mathrm{mg} \\
40 \mathrm{mg} \\
\end{array}$ & [7] \\
\hline Ekstrak sarang semut - rosella & Maltodekstrin & $\begin{array}{ll}\text { 1. } & \text { PVP } \\
\text { 2. } & \text { Asam sitrat } \\
\text { 3. } & \text { Asam tartrat } \\
\text { 4. } & \text { Natrium bikarbonat } \\
\text { 5. } & \text { Gula } \\
\text { 6. } & \text { Magnesium stearate }\end{array}$ & $\begin{array}{l}1 \% \\
5 \% \\
10 \% \\
18 \% \\
35 \% \\
1 \%\end{array}$ & {$[30]$} \\
\hline Ekstrak kulit manggis & {$[-]$} & $\begin{array}{ll}\text { 1. } & \text { Natrium bikarbonat } \\
\text { 2. } & \text { Asam sitrat } \\
\text { 3. } & \text { Asam askorbat } \\
\text { 4. } & \text { Aerosil } \\
\text { 5. } & \text { Aspartam } \\
\text { 6. } & \text { Magnesium stearate }\end{array}$ & $\begin{array}{l}1.455 \mathrm{mg} \\
970 \mathrm{mg} \\
7 \mathrm{mg} \\
35 \mathrm{mg} \\
500 \mathrm{mg} \\
35 \mathrm{mg} \\
\end{array}$ & [31] \\
\hline $\begin{array}{l}\text { Ekstrak kulit buah naga merah } \\
\text { dan buah salam }\end{array}$ & {$[-]$} & $\begin{array}{ll}\text { 1. } & \text { Asam sitrat } \\
\text { 2. } & \text { Asam tartrat } \\
\text { 3. } & \text { Natrium Bikarbonat } \\
\text { 4. } & \text { Gula } \\
\text { 5. } & \text { Mg Stearat } \\
\text { 6. } & \text { PVP } \\
\end{array}$ & $\begin{array}{l}5 \% \\
10 \% \\
18 \% \\
35 \% \\
1 \% \\
1 \% \\
\end{array}$ & [6] \\
\hline $\begin{array}{l}\text { Campuran mikroenkapsul ekstrak } \\
\text { kering foshou fruit }\end{array}$ & {$[-]$} & $\begin{array}{ll}\text { 1. } & \text { Asam sitrat } \\
\text { 2. } & \text { Natrium bikarbonat } \\
\text { 3. } & \text { Stevia }\end{array}$ & $\begin{array}{l}20 \% \\
30 \% \\
10 \%\end{array}$ & [32] \\
\hline
\end{tabular}


Bahan tambahan lainnya seperti pengisi, pengikat, pemanis dan lubrikan pada sediaan efervesen digunakan dengan mempertimbangkan kelarutanya dalam air. Bahan tambahan yang digunakan harus larut sempurna dalam air sehingga tidak meninggalkan residu [35]. Berdasarkan hasil telaah, pengikat yang paling banyak digunakan yaitu polivinilpirolidon (PVP) yang dianggap sebagai pengikat efektif. PVP dapat ditambahkan ke dalam formulasi dalam bentuk kering atau sudah terlarut dalam pelarut organik [36]. Konsentrasi PVP yang digunakan sebagai pengikat sebesar 1-2\% [6,7,20,21,25,27-30]. Kemudian pada Tabel 2 ditunjukkan pemanis yang digunakan pada setiap literatur bervariasi diantaranya aspartam, manitol, sukrosa, sakarin dan stevia. Aspartam merupakan pemanis sintetik 180 kali lebih kuat dibandingkan sukrosa [37]. Magnesium stearate digunakan sebagai lubrikan dengan konsentrasi 1\% [6,7,30]. Penggunaan lubrikan dapat menurunkan friksi antar partikel sehingga mampu meningkatkan laju alir partikel [38].

\section{Evaluasi Sediaan Efervesen}

Secara keseluruhan parameter evaluasi pada sediaan efervesen sama dengan evaluasi tablet atau granul pada umumnya. Evaluasi dilakukan untuk mengetahui dan mengkontrol kualitas sediaan efervesen [33]. Hasil evaluasi waktu larut menjadi sangat penting pada sediaan efervesen. Waktu larut dapat digunakan sebagai indikator kualitas sediaan efervesen [39]. Berdasarkan hasil telaah sumber data, hasil evaluasi waktu larut memiliki kisaran waktu 5,14 224,4 detik. Hasil uji tersebut memenuhi persyaratan menurut BPOM yaitu tidak lebih dari 5 menit.

Tabel 3. Hasil Evaluasi Waktu Larut Sediaan Efervesen

\begin{tabular}{|c|c|c|}
\hline Pustaka & Bentuk Sediaan & Waktu Larut (detik) \\
\hline$[25]$ & Serbuk & 170 \\
\hline$[23]$ & Serbuk & 5,14 \\
\hline$[8]$ & Serbuk & 224,4 \\
\hline$[20]$ & Granul & 60 \\
\hline$[27]$ & Granul & 45,5 \\
\hline$[28]$ & Granul & 203 \\
\hline$[29]$ & Tablet & 106,74 \\
\hline$[7]$ & Tablet & 195,6 \\
\hline$[30]$ & Tablet & 73,15 \\
\hline$[31]$ & Tablet & 118,8 \\
\hline$[6]$ & Tablet & 72,4 \\
\hline$[33]$ & Tablet & 134,4 \\
\hline
\end{tabular}

Tabel 4 memperlihatkan evaluasi pra-kompresi untuk sediaan berbentuk serbuk, granul dan tablet serta evaluasi pasca kompresi untuk sediaan tablet. Pada beberapa penelitian sediaan serbuk efervesen ditemukan hasil uji kadar air tidak memenuhi persyaratan [8,23]. Menurut Peraturan Badan POM kadar air dalam sediaan efervesen herbal yaitu <5\% [40]. Kadar air dalam sediaan efervesen harus dikontrol untuk mencegah terjadinya reaksi efervesen yang dapat mengganggu stabilitas sediaan salama masa penyimpanan. Salah satu upaya dengan cara 
mengkondisikan kelembaban lingkungan produksi yaitu kelembaban relatif (RH) $40 \%$ dan suhu $25^{\circ} \mathrm{C}$ [41]. Tabel 4 juga memperlihatkan hasil evaluasi $\mathrm{pH}$. Secara keseluruhan $\mathrm{pH}$ sediaan efervesen mendekati $\mathrm{pH}$ netral yaitu berada pada kisaran 4,48 - 6,8 [20,23,27,29]. Sediaan efervesen dikatakan baik jika memiliki $\mathrm{pH}$ mendekati netral [42]. Sediaan efervesen yang terlalu asam dapat mengiritasi lambung sedangkan sediaan yang terlalu basa akan menimbulkan rasa pahit [20].

Pada penelitian lainnya dilakukan evaluasi mengenai laju alir. Secara keseluruhan evaluasi laju alir yang dilakukan memiliki kisaran nilai 4,43 - 19,85 gram/detik dengan kategori baik hingga sangat baik [8,20,25,29,31,33,43]. Pada penelitian Khumaida didapat laju alir sebesar 3,31gram/detik dengan kategori sukar [7,43]. Kemudian hasil uji sudut diam yang dilakukan memiliki kisaran nilai $21,7-29,5^{\circ}$ dengan kategori baik hingga istimewa $[20,25,28,29,33,43]$. Hanya pada penelitian Hudha dan Khumaida didapat hasil uji sudut diam dengan kategori cukup baik [7,8,43].

Tabel 4. Evaluasi Sediaan Efervesen

\begin{tabular}{|c|c|c|c|c|c|}
\hline Pustaka & Bentuk Sediaan & \multicolumn{2}{|c|}{ Evaluasi Pre-Kompresi } & \multicolumn{2}{|c|}{ Evaluasi Pasca Kompresi } \\
\hline$[24]$ & Serbuk & $\begin{array}{l}\text { 1. Kadar air } \\
\text { 2. Kelarutan }\end{array}$ & $\begin{array}{l}3,62 \% \\
15 \%\end{array}$ & \multicolumn{2}{|l|}{$[-]$} \\
\hline [25] & Serbuk & $\begin{array}{l}\text { 1. Laju alir } \\
\text { 2. Sudut diam } \\
\text { 3. Kompresibilitas }\end{array}$ & $\begin{array}{l}9,10 \mathrm{~g} / \mathrm{s} \\
29,5^{\circ} \\
21,33\end{array}$ & \multicolumn{2}{|l|}{$[-]$} \\
\hline [23] & Serbuk & $\begin{array}{l}\text { 1. Kadar air } \\
\text { 2. } \mathrm{pH}\end{array}$ & $\begin{array}{l}8,73 \% \\
4,48\end{array}$ & \multicolumn{2}{|l|}{$[-]$} \\
\hline [8] & Serbuk & $\begin{array}{l}\text { 1. Laju alir } \\
\text { 2. Sudut diam } \\
\text { 3. Kadar air }\end{array}$ & $\begin{array}{l}19,85 \mathrm{~g} / \mathrm{s} \\
40,30^{\circ} \\
7,77 \%\end{array}$ & \multicolumn{2}{|l|}{$[-]$} \\
\hline [20] & Granul & $\begin{array}{l}\text { 1. Laju alir } \\
\text { 2. Sudut diam } \\
\text { 3. Kadar air } \\
\text { 4. } \mathrm{pH}\end{array}$ & $\begin{array}{l}5,81 \mathrm{~g} / \mathrm{s} \\
21,7^{\circ} \\
2,07 \% \\
5,61\end{array}$ & \multicolumn{2}{|l|}{$[-]$} \\
\hline [27] & Granul & $\begin{array}{l}\text { 1. Kadar air } \\
\text { 2. } \mathrm{pH}\end{array}$ & $\begin{array}{l}1,07 \% \\
6,8\end{array}$ & \multicolumn{2}{|l|}{$[-]$} \\
\hline [28] & Granul & $\begin{array}{l}\text { 1. Laju larut } \\
\text { 2. Sudut diam } \\
\text { 3. Hausner ratio } \\
\text { 4. Carr's index }\end{array}$ & $\begin{array}{l}203 \text { detik } \\
24,5^{\circ} \\
1,137 \\
9,6\end{array}$ & \multicolumn{2}{|l|}{$[-]$} \\
\hline [29] & Tablet & $\begin{array}{l}\text { 1. Laju alir } \\
\text { 2. Sudut diam } \\
\text { 3. Kadar air } \\
\text { 4. } \mathrm{pH} \\
\text { 5. Kompresibilitas }\end{array}$ & $\begin{array}{l}4,614 \mathrm{~g} / \mathrm{s} \\
27,939^{\circ} \\
3,340 \% \\
6,435 \\
14,14\end{array}$ & $\begin{array}{l}\text { 1. Kekerasan } \\
\text { 2. Kerapuhan } \\
\text { 3. Keseragaman bobot }\end{array}$ & $\begin{array}{l}5,588 \mathrm{~kg} \\
0,548 \% \\
\pm 471,025 \mathrm{mg}\end{array}$ \\
\hline [7] & Tablet & $\begin{array}{l}\text { 1. Laju alir } \\
\text { 2. Sudut diam }\end{array}$ & $\begin{array}{l}3,31 \mathrm{~g} / \mathrm{s} \\
36,9^{\circ}\end{array}$ & $\begin{array}{l}\text { 1. Kekerasan } \\
\text { 2. Kerapuhan }\end{array}$ & $\begin{array}{l}7,3 \mathrm{~kg} \\
0,39 \%\end{array}$ \\
\hline [30] & Tablet & \multicolumn{2}{|l|}{ - } & 1. Kadar air & $12,32 \%$ \\
\hline [31] & Tablet & 1. Laju alir & $4,43 \mathrm{~g} / \mathrm{s}$ & 1. Kekerasan & $4,87 \mathrm{~kg}$ \\
\hline [6] & Tablet & \multicolumn{2}{|c|}{$[-]$} & 1. Kadar air & $11,22 \%$ \\
\hline
\end{tabular}


Pada sediaan tablet efervesen dilakukan evaluasi kekerasan dan kerapuhan tablet. Kekerasan tablet menggambarkan kekuatan tablet untuk dapat menahan tekanan pada saat proses produksi, pengemasan dan pengangkutan [43]. Hasil evaluasi kekerasan tablet efervesen memiliki kisaran 4 - $7 \mathrm{~kg}$ [7,29,31] dan memenuhi persyaratan kekerasan tablet [43]. Sedangkan kerapuhan tablet menggambarkan kekuatan tablet terhadap gesekan yang dialami sewaktu proses pengemasan, pengiriman dan penyimpanan dan merupakan cara lain untuk mengukuran kekuatan tablet [43]. Secara keseluruhan hasil uji kerapuhan kurang dari 1\% dan memenuhi persyaratan [7,29,31]. Menurut Ansel tablet yang baik memiliki kerapuhan <1\% [43].

Selanjutnya untuk mengetahui daya aktivitas antioksidan dalam sediaan efervesen maka dilakukan evaluasi mengenai aktivitas antioksidan. Berdasarkan hasil telaah, metode DPPH (2,2 diphenyl-1-picrylhydrazyl) menjadi metode pengujian aktivitas antioksidan yang paling banyak digunakan. Pengujian dengan metode DPPH dapat menghasilkan informasi mengenai aktivitas antioksidan yang dilihat berdasarkan persen penghambatan dan nilai IC $_{50}$ yang dibandingkan dengan senyawa lain dengan aktivitas antioksidan yang baik seperti asam askorbat. Nilai IC $_{50}$ merupakan nilai konsentrasi antioksidan yang diperlukan untuk meredam $50 \%$ aktivitas radikal bebas [44]. Semakin rendah nilai $\mathrm{IC}_{50}$ maka akan semakin tinggi kadar senyawa antioksidan yang terkandung di dalam sampel yang dianalisis [45].

Tabel 5. Uji Aktivitas Antioksidan Sediaan Efervesen Herbal

\begin{tabular}{|c|c|c|c|}
\hline Sumber Herbal & Metode Uji & Aktivitas Antioksidan & Pustaka \\
\hline Buah Belimbing Wuluh (Averrhoa billimbi L.) & DPPH & $95,95 \%$ & [24] \\
\hline Cincau Hitam; Daun Pandan; Jahe & DPPH & $\mathrm{IC}_{50}=64,92 \mathrm{ppm}$ & {$[25]$} \\
\hline Daun mengkudu (Morinda citirfolia L.) & DPPH & $63,33 \%$ & {$[23]$} \\
\hline Daun Beluntas (Pluchea indica L.) & DPPH & $\mathrm{IC}_{50}=86,21 \mathrm{ppm}$ & {$[8]$} \\
\hline Miana (Coleus (L.) benth) & DPPH & $81,81 \%$ & {$[26]$} \\
\hline Daun gambir (Uncaria gambier Roxb). & DPPH & $90,94 \%$ & [20] \\
\hline $\begin{array}{l}\text { Daun The (Camellia sinensis) dan Daun Sirsak } \\
(\text { Annona muricata })\end{array}$ & DPPH & $\mathrm{IC}_{50}=26,90 \mathrm{ppm}$ & [27] \\
\hline $\begin{array}{l}\text { Artichoke (Cynara scolymus L.), borage (Borago } \\
\text { officinalis L.), brokoli (Brassica oleracea L.), } \\
\text { asparagus (Asparagus officinalis L.), bean } \\
\text { (Phaseolus vulgaris L.), lada (Capsicum annum L.), } \\
\text { tomat (Lycopersicum esculentum Mill.), wortel } \\
\text { (Daucus carota } \text { L.) dan lemon (Citrus limonum). }\end{array}$ & $\begin{array}{l}\text { FRAP dan } \\
\text { ABTS }\end{array}$ & $\begin{array}{c}\text { FRAP : } 289.843,14 \\
\text { nmol Fe }{ }^{12} \mathrm{eq} / \mathrm{g} \\
\text { ABTS : } 159,896 \mathrm{mmol} \\
\text { Trolox }\end{array}$ & [21] \\
\hline $\begin{array}{l}\text { Labu Siam (Sechium edule Sw) dan Kayu Secang } \\
\text { (Caesalpnia sappan L.) }\end{array}$ & DPPH & $3,345 \%$ & [29] \\
\hline Kulit Buah Rambutan (Nephelium lappaceum) & DPPH & $\mathrm{IC}_{50}=131 \mathrm{ppm}$ & [7] \\
\hline $\begin{array}{l}\text { Sarang Semut (Myrmecodia tuberosa) dan Bunga } \\
\text { Rosella (Hibiscus sabdarisffa L) }\end{array}$ & DPPH & $53,97 \%$ & [30] \\
\hline Kulit Buah Manggis (Garcinia Mangostana L.) & DPPH & $32,42 \mathrm{ppm}$ & [31] \\
\hline Amla (Emblica officinalis) & DPPH & $\mathrm{IC}_{50}=32 \mathrm{ppm}$ & {$[28]$} \\
\hline $\begin{array}{l}\text { Kulit buah naga merah (Hylocereus polyrhizus) dan } \\
\text { Buah Salam (Syzygium polyanthum) }\end{array}$ & DPPH & $63,13 \%$ & [6] \\
\hline Kulit buah jeruk mandarin & DPPH & $27,10 \%$ & [2] \\
\hline Buah jeruk cakar harimau & DPPH & $\mathrm{IC}_{50}=24,23$ & [32] \\
\hline Buah jambu merah dan buah naga merah & DPPH & $\mathrm{IC}_{50}=55$ & [33] \\
\hline
\end{tabular}


Berdasarkan hasil telaah sumber data terdapat beberapa kategori aktivitas antioksidan dari sediaan efervesen. Tablet efervesen ekstrak daun teh dan daun sirsak, tablet efervesen ekstrak daun amla, tablet efervesen kulit buah manggis dan tablet efervesen jeruk cakar harimau dikategorikan memiliki aktivitas antioksidan sangat kuat karena nilai IC 50 kurang dari 50ppm $[27,28,31,32,46]$. Serbuk efervesen ekstrak cincau hitam, serbuk efervesen esktrak daun beluntas dan tablet efervesen esktrak buah jambu merah dan buah naga merah memiliki aktivitas antioksidan kuat karena nilai IC $_{50}$ berada pada kisaran 50-100ppm [8,25,33,46]. Sedangkan tablet efervesen ekstrak kulit buah rambutan dikategorikan memiliki aktivitas antioksidan sedang karena nilai $\mathrm{IC}_{50}$ yang dihasilkan lebih dari 100ppm [7,46].

Penelitian di Spanyol mengenai uji aktivitas antioksidan pada granul efervesen dilakukan menggunakan metode FRAP dan ABTS. Hasil uji aktivitas antioksidan paling tinggi ditunjukkan oleh sediaan granul efervesen dibandingkan bentuk sediaan lainnya [21]. Beberapa faktor yang mempengaruhi aktivitas antioksidan dalam suatu sediaan adalah suhu proses pembuatan dan nilai $\mathrm{pH}$. Semakin tinggi suhu proses pembuatan dan nilai $\mathrm{pH}$ cenderung akan menurunkan aktivitas antioksidan [23,29].

Sediaan efervesen dapat dijadikan pilihan sebagai bentuk penghantaran antioksidan dari berbagai herbal baik dalam bentuk serbuk, granul maupun tablet. Formulasi sediaan efervesen yang paling optimum dan metode pembuatan yang tepat dapat menghasilkan sediaan efervesen yang baik serta dapat menjaga kualitas dan kadar antioksidan yang terkandung.

\section{DAFTAR RUJUKAN}

[1] A. M. El-hassan., M. E. Shayoub., M. Abdalkreem,. H. M. Osman, and K. Khalifa. Design, Formulation, and Evaluation of Senna Effervescent Tablets. J For Prod Ind. 2012, 1(2), 21-25.

[2] Ö. Tokuşoğlu. Innovative mandarin peel effervescent tablet as antioxidant and anticarcinogen food supplement: bioactive flavanones and phenolic acids by HPLC-DAD and LC-esiqtoff mass spectrometry. Food Heal Technol Innov. 2018, 1(2), 75-80.

[3] L. Pangrazzi. Boosting the immune system with antioxidants: Where are we now? Biochem (Lond). 2019, 41(1), 42-44.

[4] K. Chandra., A. S. Salman., A. Mohd., R. Sweety., K. N. Ali. Protection against FCA induced oxidative stress induced DNA damage as a model of arthritis and In vitro anti-arthritic potential of Costus speciosus Rhizome extract. Int J Pharmacogn Phytochem Res. 2015, 7(2), 383-389.

[5] S. H. Hong., K. T. Suk., S. H. Choi., J. W. Lee., H. T. Sung., C. H. Kim, et al. Anti-oxidant and natural killer cell activity of Korean red ginseng (Panax ginseng) and urushiol (Rhus vernicifera Stokes) on non-alcoholic fatty liver disease of rat. Food Chem Toxicol. 2013, 55, 586-591, doi: 10.1016/j.fct.2013.01.022

[6] Y. S. Pribadi., Sukatiningsih., P. Sari. Formulasi Tablet Effervescent Berbahan Baku Kulit Buah Naga Merah. Berk Ilm Pertan. 2014, 1(4), 86-89.

[7] A. Khumaida., D. Mulyawati., I. Irawati., N. Prawati., F. Amrillah. FORMULASI TABLET 
EFFERVESCENT BERBAHAN BAKU EKSTRAK KULIT BUAH RAMBUTAN (Nephelium lappaceum) SEBAGAI ANTIOKSIDAN. Indones J Pharm Sci Technol. 2017, VI(1), 27-36.

[8] M. Hudha., T. D. Widyaningsih. Serbuk Effervescent Berbasis Ekstrak Daun Beluntas (Pluchea Indica Less) Sebagai Sumber Antioksidan Alami. J Pangan dan Agroindustri. 2014, 3(4), 14121422.

[9] A. N. Wulansari. Alternatif Cantingi Ungu (Vaccinium varingiaefolium) Sebagai Antioksidan Alami : Review. Farmaka. 2018, 16(2), 419-429.

[10] M. Mahdiyyah., I. M. Puspitasari., N. A. Putriana., M. R. A. Syamsunarno. Review: Formulasi dan Evaluasi Sediaan Oral Effervescent. Maj Farmasetika. 2020, 5(4), 191-203.

[11] P. Negi., D. M. K. Mishra., P. D. P. Kothiyal. a Review Article on the Oral Dosage Form: Tablets. World J Pharm Res. 2017, 6(10), 264-271.

[12] C. Anam., R. D. Setiawan. KAJIAN KARAKTERISTIK FISIK DAN SENSORI SERTA AKTIVITAS ANTIOKSIDAN DARI GRANUL EFFERVESCENT BUAH BEET (Beta vulgaris) DENGAN PERBEDAAN METODE GRANULASI DAN KOMBINASI SUMEBR ASAM. $J$ TEKNOSAINS PANGAN. 2013, 2(2), 21-28.

[13] S. G. Patel., M. Siddaiah. Formulation and evaluation of effervescent tablets: a review. J Drug Deliv Ther. 2018, 8(6), 296-303.

[14] D. A. Oktavia., D. Fithriani., P. Martosuyono. Physical Characteristics of Probiotic Effervescent Tablets with Various Concentration of Maltodextrin as Coating Materials. ISMFR. 2020, 3(03023), 1-8.

[15] A. Davoodi., H. B. Jouybari., H. Fathi., P. Ebrahimnejad. FORMULATION AND PHYSICOCHEMICAL EVALUATION OF MEDLAR (MESPILUS GERMANICA L.) AND OAK (QUERCUS CASTANEIFOLIA C. A. MEY.) EFFERVESCENT TABLETS. Int $J$ Pharm Sci Res. 2018, 9(9), 3870-3875.

[16] S. Surini., M. R. W. Wardani., E. Sagita. Evaluating of effervescent tablets containing grape seed (Vitis vinifera L.) extract as a nutraceutical. Int J Appl Pharm. 2017, 9(1), 150-153.

[17] Y. H. Diza., A. Asben., T. Anggraini. Pembuatan tablet effervescent berbahan aktif sediaan kering ekstrak daun senduduk dan bakteri asam laktat asal dadih Sijunjung sebagai minuman fungsional. J Litbang Ind. 2019, 9(1), 59.

[18] D. Haack., I. Gergely, C. Metz. The TOPO Granulation Technology Used in the Manufacture of Effervescent Tablets. Techno Pharm. 2012, 191(3), 1-5.

[19] A. I. Nagashima., P. E. Pansiera., M. M. Baracat., R. J. H. C. Gómez. Development of effervescent products, in powder and tablet form, supplemented with probiotics Lactobacillus acidophilus and Saccharomyces boulardii. Food Sci Technol. 2013, 33(4), 605-611.

[20] S. I. Kailaku., J. Sumangat. Formulasi Granul Efervesen Kaya Antioksidan dari Ekstrak Daun Gambir. pascapanen. 2012, 9(1), 27-34.

[21] Romero-de Soto MD, García-Salas P, Fernández-Arroyo S, Segura-Carretero A, FernándezCampos F, Clares-Naveros B. Antioxidant Activity Evaluation of New Dosage Forms as Vehicles for Dehydrated Vegetables. Plant Foods Hum Nutr. 2013, 68(2), 200-206.

[22] K. İpci., T. Öktemer., L. Birdane., N. Altıntoprak, et al. Effervescent tablets: a safe and practical 
delivery system for drug administration. ENT Update. 2016, 6(1), 46-50.

[23] U. Regiarti., W. H. Susanto. Pengaruh Konsentrasi Asam Malat dan Suhu terhadap Karakteristik Fisik Kimia dan Organoleptik effervescent Ekstrak Daun Mengkudu (Morinda citrifolia L.). $J$ Pangan dan Agroindustri. 2015, 3(2), 638-649.

[24] Haslina., S. B. Wahjuningsih. Application of flower extract wuluh star fruit (Averrhoa Billimbi L.) on effervescent powder. Int J Adv Sci Eng Inf Technol. 2015, 5(5), 370-373.

[25] G. Prasetyo., I. Z. Zumroh., N. Etikasari., R. F. Wajdi., T. D. Widyaningsih. Formulasi Serbuk Effervescent Berbasis Cincau Hitam Dengan Penambahan Daun Pandan dan Jahe Merah. $J$ Pangan dan Agroindustri. 2015, 3(1), 90-95.

[26] D. Rizal., W. D. R. Putri. PEMBUATAN SERBUK EFFERVESCENT MIANA (Coleus (L) benth): KAJIAN KONSENTRASI DEKSTRIN DAN ASAM SITRAT TERHADAP KARAKTERISTIK SERBUK EFFERVESCENT. J Pangan dan Agroindustri. 2014, 2(4).

[27] F. S. Masitha., R. Febriansah. Antioxidant Activity from the Combination of Ethanolic Extract of Tea Leaves (Camellia sinensis) and Soursop Leaves (Annona muricata 1.) and Optimation of the Effervescent Granule Production. Mutiara Med J Kedokteran dan Kesehatan. 2019, 19(2), 56-63.

[28] N. Madhavi., D. Kumar., S. Naman., M. Singh., P. Amol Singh, N. Bajwa, et al. Formulation and Evaluation of Novel Herbal Formulations Incorporated with Amla Extract for Improved Stability. J Drug Deliv Ther. 2019, 9(4), 212-221.

[29] N. D. Sulistiani., C. Anam., B. Yudhistira. KARAKTERISTIK TABLET EFFERVESCENT LABU SIAM (Sechium edule Sw.) DAN EKSTRAK SECANG (Caesalpinia sappan L.) DENGAN FILLER LAKTOSA-MANITOL. J Teknologi Hasil Pertanian. 2018, 11(2), 99.

[30] I. Purwati., S. Yuwanti., P. Sari. Karakterisasi Tablet Effervescent Sarang Semut (Myrmecodia tuberose) - Rosella (Hibiscus sabdarisffa L.) Berbahan Pengisi Maltodekstrin dan Dekstrin. $J$ Agroteknologi. 2016, 10(01), 63-72.

[31] W. Widowati., D. Rusmana., H. Herdiman, H. Tiono, T. L. Wargasetia., W. Suttirak, et al. Mangosteen Peel (Garcinia mangostana L.) Extract for Effervescent Tablet. World Acad Sci Eng Technol. 2013, 51(82), 190-195.

[32] A. A. Mahdi., Q. A. Al-maqtari., M. I. Ahmed., W. Al-ansi. Bioactive Compounds Bioavailability of Microencapsulated Foshou Fruit Effervescent Tablets : in Vitro Simulated Gastrointestinal. Int J Agric Innov Res. 2019, 8(2), 122-132.

[33] L. P. Zea., Y. A. Yusof., M. G. Aziz., C. N. Ling., N. A. M. Amin. Compressibility and dissolution characteristics of mixed fruit tablets made from guava and pitaya fruit powders.

Powder Technol. 2013, 247, 112-9, doi: 10.1016/j.powtec.2013.06.032

[34] M. Ramadhia., S. Kumalaningsih., I. Santoso. Pembuatan Tepung Lidah Buaya (Aloevera L.) dengan Metode Foam-Mat-Drying. J Teknologi Pertanian. 2012, 13(2),125-137.

[35] D. A. Oktavia., D. Fithriani., D. Febrianti. Physical Properties of Probiotic Effervescent Tablets from Tapioca and Maltodextrin Coatings. ISMFR. 2020, 3(03024), 1-10.

[36] A. Aslani., F. Fattahi. Formulation, characterization and physicochemical evaluation of potassium citrate effervescent tablets. Adv Pharm Bull. 2013, 3(1), 217-225.

[37] V. T. Nguyen. Effect of binder and sweeteners on the production of effervescent artichoke (Cynara 
scolymusL.) tea tablets. J Food Process Preserv. 2013, 37(6), 1078-1083.

[38] A. Jamar., M. S. Anuar., S. M. Tahir. Frictional effects, mechanical strength, and disintegration of coffee mix tablet, effervescent coffee mix tablet and with added lubricant. Part Sci Techno. 2020, 38(7), 892-897. doi: 10.1080/02726351.2019.1666950

[39] Ansar. Pengaruh Suhu dan Kelembaban Udara Terhadap Perubahan Mutu Tablet Effervescen Sari Buah Selama Penyimpanan. J Teknologi dan Industri Pangan. 2011, 22(1), 73-77.

[40] Badan Pengawas Obat dan Makanan. Persyaratan Mutu Obat Tradisional. Jakarta: Kepala Badan Pengawas Obat dan Makanan; 2014.

[41] R. Dewi., Iskandarsyah., D. Octarina. Formulasi Granul dan Tablet Effervescent Ekstrak Belimbing Wuluh (Averrhoa bilimbi L.) dengan Variasi Kadar Pemanis Aspartam. Pharm Sci Res. 2014, 1(2), 116-133.

[42] L. Lachman., H. A. Lieberman., J. B. Schwartz. Pharmaceutical Dosage Forms: Tablets. 2nd ed. Vol. I. New York: Marcel Dekker, Inc; 1989.

[43] H. C. Ansel., L. V. J. Allen. Pharmaceutical Dosage Forms and Drug Delivery Systems. 10th ed. United States of America: Lippincott WIlliams \& Wilkins; 2014.

[44] F. Setiawan., O. Yunita., A. Kurniawan. Uji Aktivitas Antioksidan Ekstrak Etanol Kayu Secang (Caesalpinia sappan) Menggunakan Metode DPPH, ABTS, dan FRAP. Media Pharm Indonesia. 2018, 2(2), 82-89.

[45] M. D. Putri., A. Arumasi., N. Kurniaty. Review Artikel: Uji Aktivitas Antioksidan Ekstrak Daging Buah Semangka dan Albedo Semangka ( Citrullus Lanatus ) dengan Metode DPPH dan FRAP. Pros Farm. 2020, 6(2), 992-997.

[46] A. Aprilia., S. Putri. Uji Aktivitas Antioksidan Senyawa Fenolik Ekstrak Metanol Kulit Batang Tumbuhan Nyiri Batu(Xylocarpus moluccensis). Unesa J Chem. 2015, 4(1), 1-6. 